\title{
Franz Mußner's Interpretation of the Epistle of James and Its Impact on Jewish-Christian Dialogue
}

\author{
Interpretacija Jakobovega pisma po Franzu \\ Mußnerju in njen vpliv na judovsko-krščanski dialog
}

\begin{abstract}
One of the protagonists of Jewish-Christian dialogue in Germany was the late Franz Mußner (1916-2016), who, in 1985, was awarded for his contribution to this field with the Buber-Rosenzweig Medal. According to his own self-reflection, he owed his »discovery« of Judaism to his work on the commentary to the Epistle of James (1964, 67.75.81.87). The motto of Mußner's commentary is a dictum of Pope Pius XII: „We Christians are also Jews." These programmatic words of the commentary oppose every strict demarcation and confrontation between Jews and Christians and demand a new questioning of Christian identity, which leads us to the question: What makes Mußner's commentary on James so important for the Jewish-Christian dialogue? This article shows that Mußner discovered a Jewish (as well as a Christian) profile of James on the basis of a theological closeness between the author of James and Jesus of the Gospels (he also drew a physical closeness between the author of the letter and Jesus). According to Mußner, this closeness was reflected in words about poor people, the image of God, faith, and justification of people.
\end{abstract}

Key Words: Jewish-Christian dialogue, Epistle of James, Lord's brother, Franz Mußner, Martin Luther, roots, Jewishness

Izvleček: Eden od protagonistov judovsko-krščanskega dialoga v Nemčiji je bil pokojni Franz Mußner (1916-2016), ki je bil leta 1985 za svoj prispevek na tem področju nagrajen z Buber-Rosenzweigovo medaljo. Glede na njegovo samorefleksijo je za njegovo »odkritje" judovstva zaslužno njegovo ukvarjanje s komentarjem k Jakobovemu pismu (1964, 67.75.81.87). Geslo Mußnerjevega komentarja je izrek papeža Pija XII.: "Tudi mi kristjani smo Judje. "Te programske besede komentarja nasprotujejo vsaki strogi razmejitvi in obračunu med Judi in kristjani ter zahtevajo nov premislek krščanske identitete, ki nas vodi do vprašanja: Zakaj je Mußnerjev komentar o Jakobu tako pomemben za judovsko-krščanski dialog? V članku bom pokazal, da je Mußner na podlagi teološke bližine med avtorjem Jakobovega pisma in Jezusa evangelijev (med njima je domneval tudi fizično podobnost) odkril židovski (pa tudi krščanski) Jakobov karakter. Po besedah Mußnerja se je ta bližina odražala v besedah o ubogih, Božji podobi, veri in opravičenosti ljudi.

Ključne besede: judovsko-krščanski dialog, Jakobovo pismo, Jezusov brat, Franz Mußner, Martin Luter, korenine, judovstvo 


\section{Introduction}

Franz Mußner (1916-2016) was one of the protagonists and one of the most important biblical theologians in Germany involved in the JewishChristian dialogue and in the process of reconciliation between Christians and Jews. As the former professor of New Testament Studies at the Catholic Theological Faculty in Regensburg (and earlier in Trier), he dedicated the second half of his career to this dialogue. In 1985, he was awarded the Buber-Rosenzweig Medal for his contribution to this very important field of Christian theology. He discovered Judaism as a phenomenon, however, thanks to an initially reluctantly accepted work (Mußner 2009, 393-398; 1999, 344-350).

The starting point of his study of Judaism and the turning point on his theological path was his work on a commentary on the Letter of James, published by Herder publishing house in 1964. Although Mußner initially had doubts about writing a commentary on what was to him a lesser known text, this work brought a significant shift in his scholarly work (Mußner 2009, 393-394). The brilliance of his commentary is also proven by the fact that this book has had five editions in Herder's series of Theological Commentaries on the New Testament (Theologische Kommentare zum Neuen Testament) and that it has even been translated into Italian. ${ }^{1}$

If one opens the commentary on the Letter of James by Franz Mußner, they will first see the motto of the book, a well-known statement of Pope Pius XII: „We Christians are also Jews. "These programmatic words of the commentary contradict every strict border and confrontation between Jews and Christians, and they demand a new questioning and rethinking of what we call Christian identity. The idea of perfection, sanctification of everyday life, poverty, the doctrine of wisdom, and the image of God are only a few thoughts and themes in the Epistle of James that Mußner recognized as Christian heritage deriving from Judaism, which signalled to him that Jewish and Christian identities are closely related to each other

1 Mußner, Franz. 1964. Der Jakobusbrief. Freiburg; Basel; Wien: Herder; 1967. 2. ed.; 1975. 3. ed.; 1981. 4. ed.; 1987. 5. ed.; Mussner, Franz. 1970. La lettera di Giacomo. Brescia: Paideia. 
(Mußner 2009, 394). Mußner's commentary, therefore, serves the purpose of getting to know Judaism again.

His interpretation of the Epistle of James, however, is - despite the impulses from the catastrophe of the Shoah that were decisive for him - not completely understandable, if we do not take into account the influence of Martin Luther on the exegesis of this text. Luther characterized this Scripture as Jewish, only because in his opinion this text does not bear any sign of Christology (but see, for example, Mareček 2017, 343-362). Luther's branding of this text as Jewish cannot be considered a positive evaluation, because in Luther's eyes the Jews - if they do not believe in Jesus Christ - are sinners (WA 55,21), stubborn people (WA 56,159; 56,$212 ; 3,331$ ), or heretics and schismatics (WA 56, 421). ${ }^{2}$ That was the reason why he argued for the removal of the Epistle of James from the New Testament canon (WA TR 5,382).

Luther's best known judgment of the Epistle of James was of course that this is "a right strawy epistle, compared to these others [Romans, Galatians, Ephesians, 1 Peter, and 1 John], for it has nothing of the nature of the Gospel about it" (WA DB 6,10). ${ }^{3}$ What the nature of the Gospel or the Gospel as such meant to Martin Luther, Franz Mußner explained in his commentary, quoting Luther's words: „The Gospel, however, means nothing else but a preaching and crying about God's grace and mercy, earned and acquired by the Lord Christ due to his death.«(WA 12,259/5ff; Mußner 1964, 45) This Gospel is the basis of Christian faith, and if that is missing in one text - as it is the case in the Epistle of James - then it cannot be considered a Christian writing and as something that relates to this Christology, that is, something that is strictly related to Jesus' Passion. Such a superficial Christology poses the question: What should we do with Jesus' teaching and his words written in the Gospels? Are they not part of the Gospel and Christology? Do Jesus' words not have any salvific meaning?

2 These are only a few examples of Luther's statements about the Jews in his writings. A complete list would go beyond the scope of this work.

3 All quotations from German literature in this text are translated by the author of this article. 
The second reason why Martin Luther did not regard the Letter of James as an apostolic writing but rather as a Jewish one is the case that James, in Luther's opinion, contradicts Paul in the question of justification (WA DB 7,384). The fact that James says that Abraham was justified by his works is for him a contradiction to Paul's words in Rom 4 (also Gal 4), according to which Abraham was only justified by his faith (WA DB 7,384). According to Martin Luther, the fact that people can justify themselves on the basis of their own deeds, namely due the works of the Law, is characteristic of Jewish teaching, whereas justification based on faith in Jesus Christ is rather related to Christian teaching (WA 57,54; WA 18,63). ${ }^{4}$ Hence, when James wrote about justification due to the works of the Law, he was leaning on Jewish tradition or Judaism. This begs not only the question of whether this view of justification is solely a characteristic of Judaism but also the possibly more important question of whether the Law is still valid and binding for Christians as well.

All in all, the fact that the author of the Letter of James was a Jew was obviously not to be positively evaluated by Martin Luther. On the other hand, we could ask: Was not Jesus a Jew who also was concerned about the deeds and observance of the Law, like the author of the Letter of James? Precisely this question was occupying Franz Mußner during his work on the commentary. Almost 500 years later, he came to the same conclusion as Martin Luther: the author of James was indeed a Jew..$^{5}$ Mußner's conclusion, however, had a different connotation: it did not lead to rejection, but to a special appreciation of the Letter of James. This brings us to the questions to which the present work seeks answers:

1. What were the key points that helped Mußner unlock the Letter of James for a new understanding of this text, which for a long time was on the margins of New Testament exegesis?

4 Franz Mußner noted a few years later that this sharp contrast between the Law and the Gospel gave new theological impulses to anti-Judaism, which also became politically virulent, so that the JewishChristian dialogue had to be reconsidered $(1991,67)$.

5 Of course, today some of Mußner's assumptions sound quite old-fashioned as we now understand even better than in his times that our usual distinction between "Jews « and "Christians« does not fit for many first and second century writings. See, for example, the approach taken by Nicklas (2014) or the articles in the impressive volume by Alkier and Leppin (2018). 
2. According to Mußner, what characterizes this writing of the Lord's brother as Jewish?

3. What implications could this answer have for the understanding of our own Christian identity?

\section{The genre of the Epistle of James and its relation to Jesus' words}

Today, the Letter of James is read by exegetes more and more as a diaspora letter. This consideration is based on the one hand on the first verse of the Epistle of James, in which the author of the Letter presents himself as someone who is in a leading position, and on the other hand on the collective addresses of the recipients. ${ }^{6}$ Such diaspora letters served to strengthen the identity of foreign communities and to strengthen the bond between communities in the motherland and communities in the diaspora (Tsuji 1997, 18).?

This genre classification of the Letter of James has been widely accepted in biblical scholarship, but until recently the Epistle of James was not at all considered a coherent writing, a fact that had a huge influence on the interpretation of our text. Martin Dibelius (1883-1947) - one of the most famous and most significant German scholars in the field of New Testament Exegesis in the $20^{\text {th }}$ century, whose commentary on James had an immense influence on all later commentaries, not only in the German-speaking world - considered the Epistle of James a parenetic writing without the existence of one central theme and as a text which incorporates different traditions written by different authors. His final conclusion was that there is no theology in the Epistle of James, but instead the text's unknown

6 For a detailed overview of early Jewish diaspora letters (i.e. the Letter of Jeremiah, beginning of the $2^{\text {nd }}$ Book of Maccabees, the Letter of Baruch at the end of the Syrian Baruch Apocalypse, the Letter of Baruch in the Paralipomena Jeremiae), see: Niebuhr (1998, 420-443); on early Christian diaspora letters (The Apostle's Decree in Acts 15,23-29; The First Epistle of Peter; The Letter of Jude; The Second Epistle of Peter, The Apocalypse of John) see Tsuji (1997, 18-37).

7 Interestingly, exegetes who consider James to be a pseudepigraphic text overlook the fact that the Diaspora letters were sent abroad from Jerusalem. They try to explain this by the fact that the author refers to the authority of the Lord's brother in Jerusalem as the motherland. 
author only gathered texts from different Hellenistic traditions without making a contribution himself. (Dibelius 1964, 13-34) ${ }^{8}$

F. Mußner, on the other hand, was a "modern ground-breaker" (Davids 1988, 3640) who disproved the immensely influential thesis of M. Dibelius that there was no place for theological considerations in the Epistle of James. This is a fundamental aspect of his commentary, upon which he elaborated mainly in the Excursuses of his commentary on James and which is significant for the exegesis of the Letter of James.

F. Mußner understood the Letter of James primarily as a letter, ${ }^{9}$ but still defined its literary genre as a parenetic Didache (Mußner 1964, 24) ${ }^{10}$ This is because of his identification of James as a teacher of the church (James 3,1 ) who enjoyed a position of high authority and responsibility in the church communities. This corresponds perfectly with the language and style of James as well as with the preface, in which he describes himself as a minister of God and of the Lord Jesus Christ. Mußner saw this title as a sign of the sovereignty and power of the author. (Mußner 1964, 24; Bauckham 2002, 17)

As already mentioned, the problem that at first glance seems to be related to the genre of the Epistle of James is the lack of a recurrent theme of parenesis. Franz Mußner found a leitmotif of the parenesis, which, on the one hand, binds the whole letter and, on the other, connects it with both the teachings of Jesus and the Jewish heritage in the Old Testament. This fundamental leitmotif is the Christianity of the deed and the fulfilment of the words. Above all, Mußner discovered this motif in the Sermon on the

8 Nevertheless, Dibelius' opinion about the genre of our text was of course not unfounded: Although the Epistle of James has a typical introduction, it does not have a typical end for a letter, as it is the case in Paul's letters. Likewise, some exegetes noticed that Revelation is also an open letter that is addressed to seven churches; still, it is generally considered as an apocalypse. (Tsuji 1997, 34-35; Bauckham 2002, 12) Although today this genre is accepted by a majority of exegetes, Christoph Burchard notes very clearly that it contains many other sub-genres, such as homily, polemic texts, catechesis, etc. He considers the Letter of James to be a monitory letter. $(2000,9)$

9 In spite of this determination of the type of letter, for Mußner, James clearly is a letter. Therefore, Tsuji's evaluation that Mußner did not differ too much from Dibelius with regard to the genre of James is not correct $(1997,8)$.

10 Independently of Mußner, Bauckham characterises the Epistle of James as "paraenetic encyclical«. For him, James is undoubtedly a letter because of the opening of the letter alone; the content of the letter, however, is of a paraenetic nature that cannot be overlooked. $(2002,13)$ 
Mount in the Gospel of Matthew, where he found numerous parallels to the text of the Epistle of James; however, in his opinion, the parallels to the Lord's words are not limited to the Sermon on the Mount alone, which we can see in the list below: ${ }^{11}$

\begin{tabular}{|c|c|}
\hline 1,5 & Mt 7,7 (Lk 11,9) \\
\hline 1,6 & Mt 21,21 (Mk 11,23f) \\
\hline 1,17 & Mt 7,11 (Lk 11,13) \\
\hline 1,22 & Mt 7,24 (Lk 6,47) \\
\hline 1,23 & Mt 7,26 (Lk 6,49) \\
\hline $2,5 \mathrm{FF}$ & Mt 5,3 (Lk 6,20) \\
\hline 2,6 & Lk 18,3 \\
\hline 2,13 & Mt 5,7 \\
\hline $2,14-26$ & Mt 25,31-46 \\
\hline $3,1-12$ & Mt $12,36 f$ \\
\hline 3,12 & Mt 7,16b (Lk 6,44b) \\
\hline 4,4 & Mt 6,24 (Lk 13,13) \\
\hline 4,9 & Lk 6,25b \\
\hline 4,10 & Mt 23,12 (Lk 14,11; 18,14) \\
\hline $4,13-15$ & Mt 6,34 \\
\hline 4,17 & Lk 12,47 \\
\hline 5,1 & Lk 6,24 \\
\hline 5,2 & Mt 6,20 (Lk 12,33b) \\
\hline 5,5 & Lk 16,19 \\
\hline 5,7 & Mk 4,26-29 \\
\hline $5,9 \mathrm{a}$ & Mt 5,22 \\
\hline $5,9 \mathrm{~b}$ & Mk 13,29 \\
\hline 5,10 & Mt 5,12b (Lk 6,23b) \\
\hline 5,12 & Mt 5,33-37 \\
\hline 5,17 & $\operatorname{Lk} 4,25$ \\
\hline 5,19 & Mt 18,15 (Lk 17,3) \\
\hline
\end{tabular}

Based on these parallel passages and similarities - which are not always fully obvious (Bauckham 2002, 74-108) - between the Epistle of James and the Gospels' written words of Jesus, Mußner concluded that these similarities mostly lay in the domain of ethics. While James was undoubtedly familiar with the ethical tradition contained in $\mathrm{Q},{ }^{12}$ he was also well

11 Mußner found 26 parallel passages between the letter of James and the words of Jesus in the Gospels. The exact number of parallel passages in the exegesis is very controversial. (1964, 48-50)

12 Regarding the Synoptic question, Mußner followed the Two-Sources Hypothesis according to which a lost, but written Gospel like text Q formed one source of Matthew and Luke. 
acquainted with the traditional heritage of the Old Testament. The Letter of James, according to Mußner, emphasises an ethical ideal that is very close to that of Jesus, especially as expressed in the Sermon on the Mount. The spirit of James' teaching is the same as the spirit of Jesus'. James is first of all Jesus' spiritual brother $(1964,51){ }^{13}$

The Letter of James for Mußner is therefore a Jewish-Christian ${ }^{14}$ Scripture that exhibits a bond between the Jewish tradition in the Old Testament and the Christian teaching in the Gospels (or the teaching of Jesus). This also gives a clear profile of Mußner's commentary on the Epistle of James: it is an interpretation that contributes to the Jewish-Christian dialogue and aims to illuminate the tensions between the Old and New Testaments as well as between early Jewish literature and the Epistle of James. (Söding and Münch 1998, 264)

\section{The Jewish theological legacy in the Epistle of James}

The strong anchorage of the Epistle of James in Jewish and Old Testament theological traditions as well as James' emphasis of the importance of deeds for the justification of people ensured that this text in the history of exegesis was understood as a Jewish Scripture par excellence (let us only remember Martin Luther's judgments). This is expressed in various ways by the exegetes of the Epistle of James. The most known quotation stems perhaps from Adolf Jülicher, who described the Epistle of James as the »the least Christian book of New Testament (Jülicher 1906, 194), while James Dunn claimed that James is "[t]he most Jewish, the most undistinctive Christian document in the New Testament«(Dunn 1977, 251).

These observations resulted in the tendency that the author and the addressees of the Letter of James have been regarded as Non-Christian Jews. This idea repeatedly appears in the history of exegesis. For example, at the beginning of the $20^{\text {th }}$ century, Adolf Schlatter claimed that James was

13 Regarding the connections between Jesus and James and the Jewish and Old Testament traditions, Bauckham (like Mußner) assumes a clear parallelism $(2002,108)$.

14 Mußner still used the term »Jewish-Christian« (»judenchristlich«) which we should probably avoid today. For an overview of the misuse of this term see Lemke (2001). 
an opponent of rabbinical Judaism in a sense of inter-Jewish discussions and that the Letter of James should be regarded as being addressed to Jews (not Jewish-Christians) in the Diaspora (1985, VI-XIII.).

In his commentary on James, Franz Mußner referred to two examples of the radical misunderstandings of James' letter at the beginning of the $20^{\text {th }}$ century. F. Spitta and L. Massebieau stated that the Letter of James is not a Christian but a Jewish Text, and they argued that, except for Jesus' name that is mentioned only twice in the Epistle and should be considered as an interpolation, nothing Christian exists in the whole epistle (Mußner 1964, 24-25; 1999, 273). Mußner assumed that these thoughts were very well connected with Martin Luther's thesis as already mentioned above (the letter was written by some Jew) (WA.TR 5,157; also Mußner 1999, 274). ${ }^{15}$

In his commentary on James, Mußner went one step back and showed to what extent the relationship of James to Judaism does not at all differ from the relationship of Jesus to Judaism. Neither have anything that could be characterized as non-Jewish. They are both rooted in Old Testament Jewish tradition, and the teachings of both brothers have some characteristics that we may call Christian. ${ }^{16}$ Mußner rightly claimed that, without Jewish tradition, Christianity would have been corrupted in the Letter of James (1964, 25-26). Here, I will present three pillars of Christianity that are derived from Jewish tradition and stressed by Mußner in his commentary. I will not closely present the often-discussed subject about

15 We are confronted with this thesis today by Dale C. Allison. Allison emphasises that »twelve tribes in diaspora should not be understood as the Jewish-Christian community, but rather as the Jewish diaspora. The first words of the letter do not identify the readers as Christians, while the author does

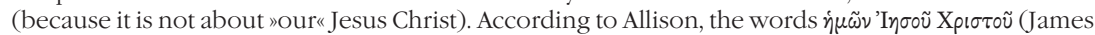
2,1 ) are certainly an interpolation (just like F. Spitta and L. Massebieau). Allison does not notice many Christian characteristics in the letter of James. He claims that the author wanted to reach an audience beyond the church. Certain Christian themes and idioms are missing in the letter of James which Allison explains with the fact that James belonged to a Jewish-Christian group that is still going to a synagogue. For this reason, he also tried to maintain relations with non-Christian Jews. That explains, according to Allison, invectives against the rich, the importance of obedience to the Torah and devotion to the work, and also why James neither quotes Jesus' statements nor mentions his miracles, his crucifixion and resurrection, or his parousia. (2013, 123-149)

16 In this article, I do not consider this Christian dimension of the Letter of James because of the scope of the work, but it would be enough to mention a few places that clearly point out Christian tradition: "1,18 ('He chose to give us birth through the word of truth, that we might be a kind of firstfruits of all he created'); 1,21 ('the word planted in you, which can save you'); 1,25 ('the perfect law of freedom'); 2,7 ('the noble name of him to whom you belong'); 5,8 ('the Lord's coming is near'); 5,12

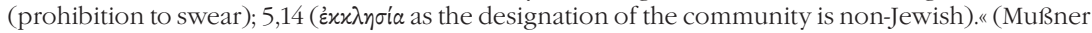
1964, 25) 
the justification of people (not only by faith) in James due to the limited scope of this article.

\subsection{The image of God in the Letter of James}

Almost fifty years have passed between Mußner's analysis of the image of God in his commentary on the Letter of James and the first thorough studies on the subject. It is certainly not a coincidence that in exegetical studies before Mußner's commentary, the Letter of James was not characterised as a theocentric Scripture, whereby the word about God and the anthropology of James correlate with one another (Frankemölle 1994, 305-320; Popkes 1986, 48). However, some exegetes do now describe the Letter of James in such a way (Popkes 1986, 48; Mareček 2017, 360). Mußner certainly had great influence on Stephan Wenger's comprehensive study about the image of God in the Letter of James, because he comes to very similar conclusions as Mußner in his commentary (Mußner 1964, 97-98; Wenger 2011, 279-290).

The starting point of the image of God in the Epistle of James is monotheism, which is a self-evident fact for James $(2,19)$, as Mußner emphasised. According to James, God is the Father $(1,17)$, and Mußner rightly added to his identity the creator of the universe. God's title xúpros (which in James' letter also refers to Jesus) indicates that he is a sovereign creator who creates a new eschatological being. (Mußner 1964, 97-98; Wenger 2011, 279-290)

Mußner saw a clear distinction between the God of the Epistle of James and pagan gods in the fact that God is »free from all demons«, that he is "pure and unambiguous in his nature and work", that "he does not tempt anyone with anything evil because »evil itself does not reach him«, and that he is "not capricious and changeable» $(1964,97)$. The image of God is - as Mußner stressed - definitely and totally identical with the Jewish image of God.

The God of the Letter of James is, on the one hand, a merciful and gracious God, and, on the other, he is the Lawgiver and the Judge, as Mußner emphasised. According to Mußner, the last two predicate from above and are strongly directed against »the rich people $(5,1-6)$ who are non-socially 
minded and who are addicted to the unconscious enjoyment of life, as well as against putative faith [...] and against any kind of unkindness towards neighbour" (Mußner 1964, 97-98). Mußner also emphasised that the God of the Epistle of James above all is a God of nearness $(4,7)$ who hears prayers $(1,5 ; 5,15-17)$ and in whose hands lies the future life of every being on earth $(4,15)$, but whose main criterion for his future judgement is love (Mußner 1964, 98).

In the end, Mußner concluded: "Thus, according to the Letter of James, God is primarily the Lord, the Father, the Judge, and thus the living God, who is not 'beyond' his work, but rather 'involved' in it in a vivid way. This distinct image of God corresponds to the image of God of the prophets and Jesus." $(1964,97)$ So, for Mußner, it is very important to stress the continuity between Old and New Testament theology and to say that the God of the Christians is not a different God compared to the Old Testament Jewish faith. But this continuity is not conceivable from Mußner's perspective without Jesus Christ, because Jesus also preached this God.

\subsection{The concept of faith in the Letter of James}

Most studies that deal with the concept of faith ( $\pi i \sigma \tau \iota \varsigma)$ in the Epistle of James consider it part of the context of the discussion about faith and deeds in relation to the doctrine of justification. Paul's words about justification by faith are an important part of such an analysis of the concept of faith in the Epistle of James. ${ }^{17}$ However, this means that the concept of faith in the Letter of James is evaluated by the scheme »Paul and/ or James (Niebuhr 2017, 473), which cannot be considered as an appropriate reflection of the concept of faith in the Letter of James (Frankemölle 1994, 223).

Franz Mußner analysed the term $\pi i \sigma \tau \iota s$ in James as a variable that is independent from Paul. His analysis of the concept of faith in James has been followed later by Wiard Popkes (1986, 202-205), Hubert Frankemölle

17 For a detailed list of literature related to such an analysis procedure, see Niebuhr (2017, 473-501, here 473). 
(1994, 222-231), ${ }^{18}$ and Rudolf Hoppe (1985, 72-118). A very large contribution to this subject in modern exegesis was also provided by K. W. Niebuhr (2017, 473-501, here 473.500; Niebuhr 2004, 1019-1044).

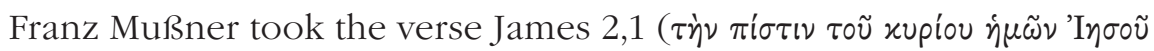

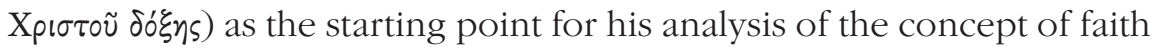
in our epistle which shows that faith is directly connected with Jesus Christ, the Lord of glory (Mußner 1964, 133; Niebuhr 2017, 473.500-501). ${ }^{19}$ The words Lord of glory have been considered by exegetes mostly to refer to the raised and exalted Lord (Frankemölle 2017, 307-329; Mareček 2017, 343-362) but Mußner focused here on the historical Jesus, or rather on the Jewish origin of Jesus because of the historical context (less than two decades after the Shoah) in which he wrote his commentary. This enabled him to say that we Christians are also Jews because the primary object of our faith is a Jew (Mußner 1964, 135). Therefore, Mußner opposed exegetical attempts that during the Nazi regime tendentiously neglected the origin of Jesus and characterised him as an Aryan, thus creating a clear, unbridgeable border between Christians and Jews (Fenske 2005, esp. 39-235). Mußner's perception of Jesus as a historical person with a Jewish origin thus had the aim to build a new bridge between Jews and Christians (1964, 136; 1999, 89-97.98-115.212-222).

For Mußner, the fact that Christians are also Jews could be seen above all in the elements that make up the term $\pi i \sigma \tau$ is. Firstly, we should mention the moment of trust. This can be seen when James refers to proper prayers (James 1,6; 5,13-18) which should be spoken without any scruple, a statement that is actually compatible with the basic characteristics of Jewish piety. The main elements of this Jewish piety are the existence and intervention of God and the trust that God will answer and respond to prayers. These elements of Jewish piety were then also adopted by the Christians (Tilly 2008, 73). Mußner was absolutely right when he said that James makes no difference between the fiducial and confessional faith, because

18 Frankemölle sees the concept of faith in the letter of James as an element that connects early Judaism and early Christianity. Characteristic features of this concept of faith are: faith that is fulfilled in works, monotheism, and the demons' belief in a God (but they do not fulfil his commandments).

19 Faith in the Letter of James is decidedly defined in Christian manner, according to Niebuhr. He also emphasises that the faith in the letter of James is oriented towards God and the Lord Jesus Christ $(1,1 ; 2,1)$. 
such a thing was not possible for the Jews (and also not for Christians). (Mußner 1964, 134; Frankemölle 1994, 223)20

A second fundamental component of the concept of faith in James is its fulfilment through the deeds of love or through helping the poor (James 1,21$27 ; 2,14-26)$, something that is not at all different from the Old Testament and Jewish practice of faith, Mußner stressed. ${ }^{21}$ The above-mentioned trust in God, who hears and helps people just like the »self-evident 'demonstration' and realization of faith due to the works of love « is "the best legacy [of the Old Testament and Judaism] and spirit of the Jesus' Spirit, who demands trust in the power of God as well as in his own power (cf. Mk 2,5; $5,34.36 ; 9,23 ; 10,52,11,22-24)$ and who rejects the people, who are saying 'Lord, Lord' (Mt 7,21)« (Mußner 1964, 135; Frankemölle 1994, 227-228). Thus, Mußner rediscovered a triangle between Judaism, Jesus' teaching, and the Epistle of James and put our epistle in a long chain of Jewish tradition that cannot be conceived without Christian (better yet, Jesus') influences. $^{22}$

The third fundamental part of the Jewish concept of faith, which Mußner called »the sanctification of everyday life«, emerges from the distance from the sinful world $(1,27 \mathrm{~b})$, the love of peace $(3,18)$, and the submission of the whole existence to the will of the Lord (4,13-15). He said:

And finally, for the Jews, faith is obedience to God's instruction [...] to sanctify everyday life; for this is the very meaning of the Law in the Jewish mind: whoever submits to the yoke of the Law on a daily basis and in everything, thereby he deprives everyday life of its profanity and sanctifies the whole existence. Judaism is the religion of holiness! (Mußner 1964, 135)

As we have seen up to now, the concept of faith in the Letter of James is certainly influenced by Jewish tradition: by trust in God, by the fulfilment

20 Bauckham claims that three dimensions of faith are present in James: "assent to true statements, trust and commitment, faithfulness «. While James makes no distinction between the last of these dimensions of faith, the first is shown in a reduction of faith to the confession of Sh'ma $(2,19)$, win order to characterize the only kind of faith which can exist without producing works« $(2002,120-121)$.

21 Niebuhr refers to this belief as »werk-tätiger Glaube« (2017, 473-501, here 500).

22 Paul advocates a realisation of faith through the works of love and stresses that there is no difference between him and James in this matter (Frankemölle 1994, 227-228). 
of this trust through the works of love, and by the sanctification/de-profanity of everyday life. In spite of its Jewish character, the concept of faith in the Letter of James is not without certain Christian characteristics. Mußner say this above all in the fact that the path of faith for James leads no longer via the Law, but via the Gospel (James 1,18). The Gospel has to be understood as the final revelation of God's will (Mußner 1964, 136). ${ }^{23}$ Whether it was even possible for a Jewish follower of Jesus to see the Torah as no longer relevant for salvation is very questionable. We see it for example in Mt 5,17 (and we know that James has many similarities with the Sermon on the Mount in Mt).

\subsection{Poverty in the Letter of James}

The care for poor people was an important characteristic of Jewish religious life and a legal-religious obligation in Judaism in which the practical side of the Jewish faith became apparent (Tilly 2008, 75). A specific tradition concerning poverty was linked to the Christian community in Jerusalem. We read this in Gal 2,9f and in Rom 15,26, where the Christian community in Jerusalem is called the poor or the poor among the saints at Jerusalem (Rom 15,26) which probably does not just reflect the social status of these people, but perhaps also their (pious) attitude.

The author of the Letter of James passionately stands up for this group of the poor and warns the rich to be helpful to the poor, which has also been done by the prophets of Israel. The relationship between the rich and the poor, and also their relationship to God is not only discussed by the prophets, but also in other Old Testament and Jewish Scriptures, in which other (sociological) dimensions of this topic are likewise visible. As a consequence, some exegetes of the Letter of James primarily look at the issue of rich and poor from a sociological point of view, neglecting

23 Contrarily, K.-W. Niebuhr, who sees the Torah and its commandments together with the Christ event as basis for his theological argumentation: „Eine dissoziierende Interpretation dieser Wendung ['Wort der Wahrheit'] entweder auf das (frühere) Reden Gottes in der Tora oder sein (gegenwärtig-endzeitliches) Offenbarungswort in Jesus Christus verkennt die theologisch-christologische Grundorientierung des Briefes. Gottes Reden und Tun in der Tora und im Christusgeschehen, in ,Gesetz und Evangelium', bildet die Basis für alles Reden und Tun der Glaubenden." (Niebuhr 2017, 473-501, here 500) 
the theological dimension of the subject (Dibelius 1964, 59-60.65), ${ }^{24}$ while other exegetes consider only the theological dimension (Maier 1980).

In the Torah, there are dozens of regulations and laws that should protect the poor. In the end, there should be no poor in Israel ( $\operatorname{Ex} 22,21-23$; 23,3.6.10f; Lev 25,2-7; 19,9f; 25,8-17; 25,23; Dtn 24,19-22). This social aspect of the term poor is also found in the prophets, who wanted to protect the poor from the rich or from the king and his ministers (Mußner 1964, 77; Schnider 1987, 119). Only in the Psalms were the poor identified with the humble in front of God or with the pious (Ps 37; 45; 146,8f; 147,6) who find their refuge by Yahweh. In this way, the term poor took on a religious dimension (Dibelius 1964, 58; Mußner 1964,77-78). Mußner summarized the meaning of being poor in this sense very well with the following words:

Because the poor - in contrast to the unjust one - stand in the proper way before God, expect all salvation only from him, and always are confident that God will help them, they are 'humble' and the ideal type of the pious so that they become the ideal of the true believer. In this sense, the Old Testament and especially the post-exile literature knows something like a specific 'piety of the poor'. (1964, 78-79)

This poverty concretizes itself in the scheme »lowering-exaltation" (Erniedrigung-Erhöhung), which was certainly noticed before Mußner, but he placed special emphasis on this (Dibelius 1964, 59). That pattern is reflected in the fact that »the poor, who are oppressed and persecuted by the rich and powerful 'enemies', [...] are saved and 'exalted' by God, and the rich will be lowered by Him« $(1964,78)$.

24 Dibelius focused on social events. He saw the causes of the poverty of the Epistle of James in the rebellion of the pious against "the profanation [...] against injustice and unfairness of the rich, as well as in the national-religious rebellion against the Hellenistic invasion « at the time of the Maccabees, which Jesus then revived again among the small farmers and craftsmen as a result of growing economic contrasts, and which then had been apparent in "aversion to the world, distrust to 'worldly' business, warning against arrogance, humble submission to God «, or in a distrust against the rich who wanted to enter the church - realised in the Letter of James.

Oda Wischmeyer remarks that Dibelius uses the socio-historical and sociological categories of his time, which do not have much to do with the $1^{\text {st }}$ century but mainly with his own time (2018, 436-453, here 449). Dibelius' influence can also be seen in Tsuji (1999, 141-144). 
This structure in the Epistle of James is also of an eschatological nature, because the poor should expect their salvation only from the returning Lord (James 5,7f), which Mußner also saw as the Christian characteristic of poverty in the Epistle of James, because, for him, the returning Lord is Jesus Christ $(1964,80)$. In this way, the conflict between rich and poor gets a theological dimension $(1964,80)$. For Mußner, the point was obvious - inasmuch behind the statements about rich and poor in the Epistle of James (like Dibelius) he saw not only a revival of the pride of the poor as a result of the entry of the rich into the church in a post-Pauline period (80-130 AD) (Dibelius 1964, 65-66), ${ }^{25}$ but primarily obvious indications of an ideal, according to which being poor and being a Christian are in harmony (Mußner 1964, 81).

Hence, Mußner did not overlook an experience that is hidden behind the words in James 2,6 (»Is it not the rich who are exploiting you? Are they not the ones who are dragging you into court? «), and that cannot be explained by the mentioned scheme. Based on his earlier dating of the Epistle of James and the comparison with the letters of Paul and the Acts of the Apostles (especially with the story about Stephen's Martyrdom and with 1 Thess 2,14-16), Mußner formulated the thesis that in James 2,6 behind the rich stand the Jews. He additionally supported this thesis with

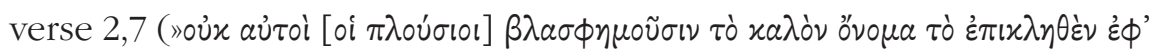
i $\left.\mu \tilde{a} \varsigma^{\prime}\right)$, which he placed in the context of a struggle between the Christians, who are now the chosen rest of Israel/the poor, and the Jews/those who blaspheme the name called upon by Christians at their baptism (Mußner 1964, 81; Hoppe 1985, 84-85). Thus, Mußner placed the Epistle of James at the centre of a theological battle (for which the term blasphemy in 2,7 speaks) between various Jewish movements before the destruction of the second Temple in 70 A.D.

Mußner's last but not least important remark about poverty in the Epistle of James is its proximity to Jesus' sermon, which was not seen in this way before Mußner's comment:

25 For Dibelius, the woes in 5,1-6 and the example in 2,2-4 are a sign of James' fear of the entry of the rich into Christian communities. 
For James and Jesus, the poor are the inheritors of the Kingdom of God. Both are throwing their 'woe' towards the rich. Both of them are warning against the greedy desires of the rich. Both are thinking in the scheme of lowering - exalting of the poor. Both are demanding concrete help for the needy neighbour and promote a 'non-limited' understanding of the term 'neighbour'. $(1964,84)$

Mußner only saw the differences between James' and Jesus' teaching about the poor in their respective styles (Jesus speaks in parables; James mentions drastic examples). In this way, Jesus could have been seen as a mediator of the Jewish tradition to Christianity, through which the Jewish heritage gets certain accents (hope for the returning Lord) (Davids 1988, 3621-3645, here 3637).

\section{Conclusions}

In the middle of the 1960s, decisive turning points occurred (not only) in Catholic biblical exegesis. The terrible pogroms against the Jews during the Second World War were a trigger for at least one aspect of this development. Exegetes had to reconsider the relationship between Judaism and Christianity. The Second Vatican Council and its impulses played significant role in this new process.

Franz Mußner, who wrote his commentary on the Epistle of James precisely at the time when the Council took place, was also inspired by these new directions and turns in theology. With his commentary, he initially wanted to make a contribution to the Jewish-Christian dialogue.

By answering the introductory questions of the Letter of James and by confronting the prevailing solutions to these questions in the exegesis of the Letter of James in the $20^{\text {th }}$ century, Mußner set our letter in a JudeoChristian environment. His reconstruction of the author's image pointed to the Lord's brother James as the author of this text. He noted that only recipients from a Jewish-Christian milieu could in fact identify themselves with the twelve tribes in Diaspora. 
Mußner recognised the relation of the Letter of James to the teachings of Jesus on the basis of numerous parallels between James and the words of Jesus in the Gospels (especially in the Q material of the Sermon on the Mount in Mt, Lk) as well as on the basis of the discovery of a basic motif that simultaneously holds the Letter of James together, characterises Jesus' teachings, and is recognisable in the Old Testament Jewish heritage: the realisation of the word or Christianity of action. The theological structure and this leitmotif of the Letter of James led Mußner to the conclusion that the author of the letter is Jesus' brother not only by blood, but also by spirit.

In order to better respond to the challenges of his time and work, Mußner tried to distinguish in the Letter of James between what is Jewish and what is Christian. He knew that Luther was right when he said that this letter was written by a Jew. Both the theology and the anthropology of the Letter of James are anchored in the writings of Israel, Mußner noted. Poverty, the image of God, and the concept of faith as well as the doctrine of justification and the promotion of synergy between faith and works in relation to the justification of people in the Letter of James can be seen through Mußner's insights as the best Jewish heritage of Christianity.

Regarding the requirement of deeds as a justifying factor (which is why the Letter of James was so often misunderstood as a purely Jewish Scripture), Mußner showed that Jesus also demanded good works from the people. Mußner also pointed out that Jesus deals with all these topics mentioned in the Gospels in a very similar way, too (piety of the poor, image of God, faith, justification). After a 2000 year long history of Christian anti-Judaism, we probably do not have the right to say that we Christians are also Jews; however, we should never forget that at the beginning of the movement that we nowadays call Christianity stood Jews like Jesus and James. When we are referring to Jesus, we are not referring to a Christian, but to a Jew.

Mußner especially emphasised this when he analysed the concept of faith in the Letter of James. He first stressed that this concept is characterised by the moment of trust, by the realisation of faith through the works of love, and by the sanctification of everyday life, which correspond in every point to the Old Testament Jewish understanding of the concept of faith. Secondly, Mußner emphasised that James and Jesus also understand the concept of faith in the same way, because Jesus, too, demands 
trust in the power of God and rejects the attitude of the people who are only saying, "Lord, Lord«, and doing nothing. But what distinguishes the concept of faith in the Letter of James so strongly from the Jewish tradition and the teachings of Jesus is the fact that its primary object is a Jew, namely Jesus Christ (James 2,1), who is at the same time the Lord of glory.

In the end, what do we learn from the Epistle of James about the Jewishness in Christianity? We learn from the Epistle of James that Christianity would indeed perish without Jewishness. Jewishness is the cornerstone and the bearer of Christian theology and anthropology. The Jewish element is not only seen in the teaching of the Letter of James, but also in the fact that Jesus Christ was a Jew who was completely anchored in his Jewish tradition. If we want to forget or ignore the Jewishness in our identity, we forget who Jesus Christ was and what our roots are. In this case, we would be like the man who builds his house on sand (Mt 7,24-27), and then we would do the opposite of what God wants us to do. ${ }^{26}$

26 I would like to express my gratitude to most supportive mentor, Prof. Dr. Tobias Nicklas - who was the initiator of this article - for his very valuable feedbacks, as well as to my colleague Charlotte von Schelling and to dear Dr. Eric Beck for their effort to improve the language of this text. 


\section{Abbreviations}

WA D. Martin Luthers Werke: kritische Gesammtausgabe (Weimarer Ausgabe)

WA TR Tischreden

WA DB Die deutsche Bibel

\section{References}

Allison, Dale C. 2013. Jas 2:14-26: Polemic against Paul, Apology for James. In: Tobias Nicklas, Andreas Merkt and Joseph Verheyden, eds. Ancient Perspectives on Paul, 123-149. Göttingen: Vandenhoeck \& Ruprecht. https://doi.org/10.13109/9783666593598.123

Bauckham, Richard. 2002. James: Wisdom of James, disciple of Jesus the sage. London; New York: Routledge.

Burchard, Christoph. 2000. Der Jakobusbrief. Tübingen: Mohr Siebeck.

Davids, H. Peter. 1988. The Epistle of James in Modern Discussion. In: Wolfgang Haase, ed. Aufstieg und Niedergang der römischen Welt: Geschichte und Kultur Roms im Spiegel der neueren Forschung, 3621-3645. Berlin; New York: De Gruyter.

Dibelius, Martin. 1933. Die Formgeschichte des Evangeliums. Tübingen: Mohr (Paul Siebeck).

Dunn, James D.G. 1977. Unity and diversity in the New Testament: An inquiry into the character of earliest Christianity. London: SCM Press.

Fenske, Wolfgang. 2005. Wie Jesus zum "Arier wurde: Auswirkung der Entjudaisierung Christi im 19. und zu Beginn des 20. Jahrhunderts. Darmstadt: WBG.

Frankemölle, Hubert. 1994. Der Brief des Jakobus. Gütersloh: GTB.

Hoppe, Rudolf. 1985. Der theologische Hintergrund des Jakobusbriefes. Würzburg: Echter-Verlag.

Jülicher, Adolf. 1906. Einleitung in das Neue Testament. Tübingen: Mohr (Paul Siebeck).

Luther, Martin. 2002. D. Martin Luthers Werke. Ed. by Ulrich Köpf. Weimar: Springer.
Maier, Gerhard. 1980. Reich und arm: Der Beitrag des Jakobusbriefes. Gießen: Brunnen Verlag.

Mareček, Petr. 2017. Die Person Jesu Christi im Jakobusbrief. Annali di storia dell esegesi 2017: 343-362.

Mußner, Franz. 1999. Autobiographische Nachschrift - Mein theologischer Weg. In: Jesus von Nazareth im Umfeld Israels und der Urkirche, 344-350. Tübingen: Mohr Siebeck.

- - -. 1999. Der »Jude« Jesus (1971). In: Jesus von Nazareth im Umfeld Israels und der Urkirche, 89-97. Tübingen: Mohr Siebeck.

- - -. 1964. Der Jakobusbrief: Auslegung. Freiburg: Herder.

- - -. 1999. Die Beschränkung auf einen einzigen Lehrer. Zu einer wenig beachteten differentia specifica zwischen Judentum und Christentum (1978). In: Jesus von Nazareth im Umfeld Israels und der Urkirche, 212-222. Tübingen: Mohr Siebeck.

- - -. 1991. Dieses Geschlecht wird nicht vergehen: Judentum und Kirche. Freiburg: Herder.

- - -. 1999. Fiel Jesus von Nazareth aus dem Rahmen des Judentums? Ein Beitrag zur "Jesusfrage" in der neutestamentlichen Jesustradition (1996). In: Jesus von Nazareth im Umfeld Israels und der Urkirche, 98-115. Tübingen: Mohr Siebeck.

- - -. 2009. Meine Entdeckung des Judentums. In: Traktat über die Juden, 393-398. Göttingen: Vandenhoeck \& Ruprecht. 
- - -. 1999. Rückbesinnung der Kirchen auf das Jüdische: Impulse aus dem Jakobusbrief (1998). In: Jesus von Nazareth im Umfeld Israels und der Urkirche, 273-285. Tübingen: Mohr Siebeck.

- - -. 2009. Traktat über die Juden. Göttingen: Vandenhoeck \& Ruprecht.

Nicklas, Tobias. 2014. Jews and Christians? Tübingen: Mohr Siebeck.

Niebuhr, Karl-Wilhelm. 2004. A new perspective on James? Neuere Forschungen zum Jakobusbrief. Theologische Literaturzeitung: Monatsschrift für das gesamte Gebiet der Theologie und Religionswissenschaft 2004: 1019-1044.

- - -. 2017. Der erinnerte Jesus bei Jakobus: Ein Beitrag zur Einleitung in einen umstrittenen Brief. In: Michael Labahn, ed. Spurensuche zur Einleitung in das Neue Testament, 307-329. Göttingen: Vandenhoeck \& Ruprecht.

- - -. 1998. Der Jakobusbrief im Licht frühjüdischer Diasporabriefe. New Testament Studies 1998: 420-443.

- - -. 2017. Glaube im Stresstest: Пi $\sigma \tau \iota \mathrm{sim}$ Jakobusbrief. In: Kathrin Hager, ed. Glaube: Das Verständnis des Glaubens im frühen Christentum und in seiner jüdischen und hellenistisch-römischen Umwelt, 473-501. Tübingen: Mohr Siebeck.
Popkes, Wiard. 1986. Adressaten, Situation und Form des Jakobusbriefes. Stuttgart: Katholisches Bibelwerk.

Schlatter, Adolf. 1985. Der Brief des Jakobus. Stuttgart: Calwer Verlag.

Schnider, Franz. 1987. Der Jakobusbrief. Regensburg: Pustet.

Söding, Thomas, and Christian Münch. 1998. Wege der Schriftauslegung: Methodenbuch zum Neuen Testament. Freiburg im Breisgau: Herder.

Tilly, Michael. 2008. So lebten Jesu Zeitgenossen: Alltag und Glaube im antiken Judentum. Stuttgart: Calwer Verlag.

Tsuji, Manabu. 1997. Glaube zwischen Vollkommenheit und Verweltlichung. Tübingen: Mohr Siebeck.

Wenger, Stefan. 2011. Der wesenhaft gute Kyrios: Eine exegetische Studie über das Gottesbild im Jakobusbrief. Zürich: TVZ.

Wischmeyer, Oda. 2018. Der Jakobusbrief. In: Eve-Marie Becker, Friedrich Wilhelm Horn, and Dietrich-Alex Koch, eds. Der "Kritisch-exegetische Kommentar in seiner Geschichte: H.A. W. Meyers KEK von seiner Gründung 1829 bis heute, 436-453. Göttingen: Vandenhoeck \& Ruprecht. 